\title{
SYNTHESIS OF $\mathrm{MoS}_{2}$ BY TREATING MOLYBDENUM IN $\mathrm{H}_{2} \mathrm{~S}$ PLASMA
}

\author{
SINTEZA $\mathrm{MoS}_{2} \mathrm{Z}$ OBDELAVO MOLIBDENA V PLAZMI $\mathrm{H}_{2} \mathrm{~S}$
}

\author{
Alenka Vesel $^{\mathbf{1}}$, Rok Zaplotnik ${ }^{\mathbf{1}}$, Nicolas Gaillard ${ }^{\mathbf{2}}$ \\ ${ }^{1}$ Jožef Stefan Institute, Jamova cesta 39, 1000 Ljubljana, Slovenia \\ ${ }^{2}$ Renewables Power Generation, Hawaii Natural Energy Institute, 1680 East West Road, POST 109, Honolulu, Hawaii, USA \\ alenka.vesel@guest.arnes.si \\ Prejem rokopisa - received: 2017-09-05; sprejem za objavo - accepted for publication: 2018-01-16
}

doi: $10.17222 / \mathrm{mit} .2017 .147$

\begin{abstract}
$\mathrm{MoO}_{3}$ samples were sulfurized in a radiofrequency plasma created in $\mathrm{H}_{2} \mathrm{~S}$ gas. The power was set to $800 \mathrm{~W}(\mathrm{H}$-mode) to achieve sufficient sample heating and thus $\mathrm{MoS}_{2}$ formation. The treatment time was varied between $2 \mathrm{~s}$ and 30 min. The samples were analysed by X-ray photoelectron spectroscopy (XPS). The results showed $\mathrm{MoS}_{2}$ formation already at short treatment times (2 s). With increasing treatment time, the sulphur concentration decreased and became negligible at $90 \mathrm{~s}$ of treatment. XPS-depth profiling showed the formation of a 5-nm-thick $\mathrm{MoS}_{2}$ layer on the sample treated for $2 \mathrm{~s}$.

Keywords: molybdenum sulphide, $\mathrm{H}_{2} \mathrm{~S}$ plasma, sulfurization, XPS

Vzorce $\mathrm{MoO}_{3}$ smo sulfurizirali v radiofrekvenčni plazmi, ustvarjeni v plinu $\mathrm{H}_{2} \mathrm{~S}$. Moč generatorja je bila 800 W (H-način razelektritve), s čimer smo dosegli zadostno gretje vzorcev in s tem tvorbo $\mathrm{MoS}_{2}$. Cas obdelave smo spreminjali med $2 \mathrm{~s}$ in 30 min. Vzorce smo analizirali z rentgensko fotoelektronsko spektroskopijo (XPS). Ugotovili smo, da se MoS, tvori že pri kratkih časih obdelave $(2 \mathrm{~s})$. S podaljševanjem časa obdelave je koncentracija žvepla upadala in pri $90 \mathrm{~s}$ obdelavi postala zanemarljiva. Pri profilni globinski analizi XPS smo na vzorcu, obdelanem $2 \mathrm{~s}$, ugotovili nastanek $5 \mathrm{~nm}$ debele plasti $\mathrm{MoS}_{2}$.

Ključne besede: molibdenov sulfid, plazma $\mathrm{H}_{2} \mathrm{~S}$, sulfurizacija, XPS
\end{abstract}

\section{INTRODUCTION}

$\mathrm{MoS}_{2}$ is an important compound belonging to transition-metal dichalcogenides. It is a layered 2D material with properties similar to graphene. ${ }^{1}$ The advantage of $\mathrm{MoS}_{2}$ over graphene is its thickness-dependent electrical and optical properties. ${ }^{2-4}$ Therefore, it is a promising material for applications in photonics and photovoltaics (solar cells), ${ }^{5-7}$ the microelectronic industry (integrated circuits, ${ }^{8}$ tunnelling transistors, ${ }^{9}$ flexible electronic devices $^{10}$ ) and for energy conversion (fuel cells, ${ }^{11}$ batteries ${ }^{12}$ ). $\mathrm{MoS}_{2}$ is usually formed by chemical vapour deposition (CVD) using $\mathrm{MoO}_{3}$ and sulphur ${ }^{1}$ or by annealing of thin evaporated molybdenum thin film in a sulphur-containing environment. ${ }^{2}$ In both cases, hightemperature is required. Najmaei et al. synthesized $\mathrm{MoS}_{2}$ by CVD at $850{ }^{\circ} \mathrm{C} .{ }^{1} \mathrm{~A}$. Tarasov et al. ${ }^{2}$ was heating the samples at $550-1050{ }^{\circ} \mathrm{C}$ for $1 \mathrm{~h}$. He found that the structural quality (stoichiometry) of $\mathrm{MoS}_{2}$ was greatly improved at higher temperatures (above $750{ }^{\circ} \mathrm{C}$ ). Weber et al. ${ }^{13}$ was heating $\mathrm{MoO}_{3}$ samples in a $\mathrm{H}_{2} \mathrm{~S}$ atmosphere for $3 \mathrm{~h}$ in the temperature range up to $400{ }^{\circ} \mathrm{C}$. The fully sulphated state of Mo appeared at temperatures between $250{ }^{\circ} \mathrm{C}$ and $400{ }^{\circ} \mathrm{C}$. X. L. Li et al. ${ }^{14}$ was heating $\mathrm{MoO}_{3}$ and sulphur in a furnace up to $850{ }^{\circ} \mathrm{C} .{ }^{14}$ Pure hexagonal $\mathrm{MoS}_{2}$ was formed at temperatures above $400{ }^{\circ} \mathrm{C}$; however, the best temperature was found to be $850{ }^{\circ} \mathrm{C}$. At temperatures below $400{ }^{\circ} \mathrm{C}$ sulfurization was not complete because $\mathrm{MoO}_{3}$ oxide was still found to coexist.
When they were investigating the effect of treatment time, they found that a short treatment time led to the coexistence of an intermediate product of $\mathrm{MoO}_{2}$ and $\mathrm{MoS}_{2}$, no matter at what temperature the reaction was performed. ${ }^{14}$

Another possibility for the synthesis of $\mathrm{MoS}_{2}$ is plasma-assisted sulfurization of $\mathrm{MoO}_{3} .{ }^{15,16}$ The advantage of using plasma is the presence of atomic and ionic species of hydrogen and sulphur, which are more reactive than $\mathrm{H}_{2} \mathrm{~S}$ itself. Kumar et al. used $\mathrm{H}_{2} \mathrm{~S} / \mathrm{Ar}$ plasma for the synthesis of $\mathrm{MoS}_{2}$ films at different temperatures (150-550 ${ }^{\circ} \mathrm{C}$ ) for 1 h. ${ }^{15} \mathrm{He}$ found similar results as $\mathrm{Li}$ et al. Above $350{ }^{\circ} \mathrm{C}$ the films were predominantly $\mathrm{MoS}_{2}$, whereas below $350{ }^{\circ} \mathrm{C}$ two phases existed: $\mathrm{MoS}_{2}$ and $\mathrm{MoO}_{2}$. Therefore, a two-step mechanism of sulfurization was suggested: the first one involving the reduction of $\mathrm{MoO}_{3}$ to $\mathrm{MoO}_{2}$, followed by the second one involving the replacement of oxygen with sulphur in $\mathrm{MoO}_{2}$ to form $\mathrm{MoS}_{2} \cdot{ }^{15}$ It was also found that the size of the $\mathrm{MoS}_{2}$ crystallites was increasing with the temperature. In another experiment, P. Kumar et al. ${ }^{16}$ compared three different techniques for $\mathrm{MoS}_{2}$ synthesis in: a) sulphur vapour, b) $\mathrm{H}_{2} \mathrm{~S} / \mathrm{Ar}$ gas and c) $\mathrm{H}_{2} \mathrm{~S} / \mathrm{Ar}$ plasma. The best results were obtained by plasma treatment, because only in this case, was the surface completely sulfurized to form highly crystalline $\mathrm{MoS}_{2}$ (with a thickness of $16 \mathrm{~nm})$.

In the papers mentioned above, the authors first prepared Mo-containing thin films, which were further 
used for sulfurization. Herein, we report on the synthesis of $\mathrm{MoS}_{2}$ using as-received molybdenum in pure $\mathrm{H}_{2} \mathrm{~S}$ plasma. In contrast to P. Kumar et al. ${ }^{15}$ we used rather short treatment times.

\section{EXPERIMENTAL PART}

\subsection{Plasma treatment}

Molybdenum foil with a thickness of $0.05 \mathrm{~mm}$ (from Goodfellow) was cut into small pieces with a size of $8 \times 8 \mathrm{~mm}^{2}$. The samples were treated by hydrogen sulphide $\left(\mathrm{H}_{2} \mathrm{~S}\right)$ plasma created in a plasma reactor that consisted of a Pyrex-glass tube with a length of $80 \mathrm{~cm}$ and a diameter of $4 \mathrm{~cm}$. A coil of 6 turns was mounted in the centre of the tube. The samples were mounted in the middle of the coil. The plasma was created by a radiofrequency (RF) generator coupled to the coil via a matching network. The generator operated at the standard frequency of $13.56 \mathrm{MHz}$ and at the nominal power of $800 \mathrm{~W}$, which allowed ignition of plasma in so called $\mathrm{H}$-mode (concentrated plasma inside the coil). The discharge tube was pumped with a rotary pump operating at the nominal pumping speed of $80 \mathrm{~m}^{3} \mathrm{~h}^{-1}$. Pressure of $\mathrm{H}_{2} \mathrm{~S}$ gas was set to $20 \mathrm{~Pa}$. The samples were treated for different periods from $2 \mathrm{~s}$ to $120 \mathrm{~s}$. The samples quickly heated up and became red hot already after $2 \mathrm{~s}$ of treatment. Therefore, one sample was also treated by pulses to prevent overheating. Four pulses with a duration of $2 \mathrm{~s}$ were applied and the results were compared with a sample treated for $8 \mathrm{~s}$. Additionally, one sample was also treated for $30 \mathrm{~min}$ at a low power of $150 \mathrm{~W}$ to avoid the sample heating by plasma. Instead, a heater was used to keep the sample temperature constant at $400{ }^{\circ} \mathrm{C}$.

\subsection{Surface characterisation}

XPS characterization of the samples was performed to determine their surface chemical changes after plasma sulfurization. An XPS instrument model TFA XPS from Physical Electronics was used. The samples were excited with monochromatic Al- $K \alpha_{1,2}$ radiation at $1486.6 \mathrm{eV}$ over an area with a diameter of $400 \mu \mathrm{m}$. Photoelectrons were detected with a hemispherical analyser positioned at an angle of $45^{\circ}$ with respect to the normal of the sample surface. XPS survey spectra were measured at a pass-energy of $187 \mathrm{eV}$ using an energy step of $0.4 \mathrm{eV}$, whereas high-resolution spectra were measured at a pass-energy of $23.5 \mathrm{eV}$ using an energy step of $0.1 \mathrm{eV}$. The measured spectra were analysed using MultiPak v8.1c software from Physical Electronics, which was supplied with the spectrometer.

To estimate the sulphur film thickness, depth profiling of the selected sample with the maximum sulphur content was performed. A beam of $\mathrm{Ar}^{+}$ions with an energy of $1 \mathrm{keV}$ and at an incidence angle of $45^{\circ}$ was used for sputtering over an area of $3 \mathrm{~mm} \times 3 \mathrm{~mm}$. This resulted in a sputtering rate of about $1 \mathrm{~nm} / \mathrm{min}$. XPS con- centration profiles were evaluated using the relative sensitivity factors from the manufacturer's handbook.

\section{RESULTS AND DISCUSSION}

Table 1 shows the XPS surface composition of the samples. For the untreated sample, carbon, oxygen and molybdenum were found. The concentration of carbon was rather high, which was a consequence of the surface contamination. The presence of oxygen with the O/Mo ratio $\sim 3$ indicates that the surface was oxidized and consisted of $\mathrm{MoO}_{3}$ as it will be shown later. For the plasmatreated samples, concentrations of carbon and oxygen were significantly reduced, and additionally, sulphur appeared. In general, three different situations can be observed in Table 1 regarding the treatment time. The samples treated up to $15 \mathrm{~s}$ had quite high sulphur and very low oxygen contents. The samples treated between $20 \mathrm{~s}$ and up to $60 \mathrm{~s}$ had low sulphur but high oxygen content. Whereas the samples treated for $90 \mathrm{~s}$ or more had only negligible amount of sulphur and very high content of oxygen.

The maximum sulphur concentration (almost $36 \%$ of amount fractions) was found already at $2 \mathrm{~s}$ of treatment. As already mentioned, with the increasing treatment time the sulphur concentration decreased and became negligible at treatment times $=90 \mathrm{~s}$. This variation of the sulphur content with treatment time is also shown in Figure 1, where the S/Mo ratio is displayed. The maximum ratio at $2 \mathrm{~s}$ of treatment was 0.96 . By considering the theoretical S/Mo ratio in $\mathrm{MoS}_{2}(\mathrm{~S} / \mathrm{Mo}=2)$, we could roughly estimate the relative content of $\mathrm{MoS}_{2}$, which was $51 \%$.

For the oxygen, the opposite variation with treatment time was observed in comparison to the sulphur. At the beginning, the initial oxygen concentration at first significantly decreased and reached the lowest concentration of approximately $6 \%$ of amount fractions. Then it started to increase with time and for the longest treat-

Table 1: XPS surface composition of the molybdenum samples treated in $\mathrm{H}_{2} \mathrm{~S}$ plasma

\begin{tabular}{|c|c|c|c|c|c|c|}
\hline $\begin{array}{c}\text { Time } \\
(\mathrm{s})\end{array}$ & $\begin{array}{c}\mathrm{C} \\
(a / \%)\end{array}$ & $\begin{array}{c}\mathrm{O} \\
(a / \%)\end{array}$ & $\begin{array}{c}\mathrm{S} \\
(a / \%)\end{array}$ & $\begin{array}{c}\mathrm{Mo} \\
(a / \%)\end{array}$ & $\mathrm{S} / \mathrm{Mo}$ & $\mathrm{O} / \mathrm{Mo}$ \\
\hline 0 & 53.9 & 34.8 & $/$ & 11.3 & $/$ & 3.07 \\
\hline 2 & 25.7 & 6.6 & 33.1 & 34.6 & 0.96 & 0.19 \\
\hline 5 & 36.1 & 6.9 & 23.8 & 33.2 & 0.72 & 0.21 \\
\hline 8 & 32.7 & 6.0 & 23.8 & 37.5 & 0.63 & 0.16 \\
\hline 15 & 34.0 & 8.6 & 18.1 & 39.4 & 0.46 & 0.22 \\
\hline 20 & 33.8 & 19.5 & 11.8 & 35.2 & 0.34 & 0.55 \\
\hline 30 & 33.8 & 19.0 & 14.5 & 32.6 & 0.45 & 0.58 \\
\hline 60 & 35.1 & 29.1 & 6.7 & 29.1 & 0.23 & 1.0 \\
\hline 90 & 36.5 & 45.1 & 0.3 & 18.1 & 0.02 & 2.5 \\
\hline 120 & 28.7 & 48.0 & 1.5 & 21.8 & 0.07 & 2.2 \\
\hline $\begin{array}{c}4 \mathrm{~s} \times 2 \mathrm{~s} \\
(\mathrm{pulsed})\end{array}$ & 31.0 & 8.2 & 26.1 & 34.8 & 0.75 & 0.23 \\
\hline $\begin{array}{c}30 \mathrm{~min} \text { at } \\
400{ }^{\circ} \mathrm{C}\end{array}$ & 44.3 & 33.1 & 8.8 & 13.8 & 0.64 & 2.4 \\
\hline
\end{tabular}




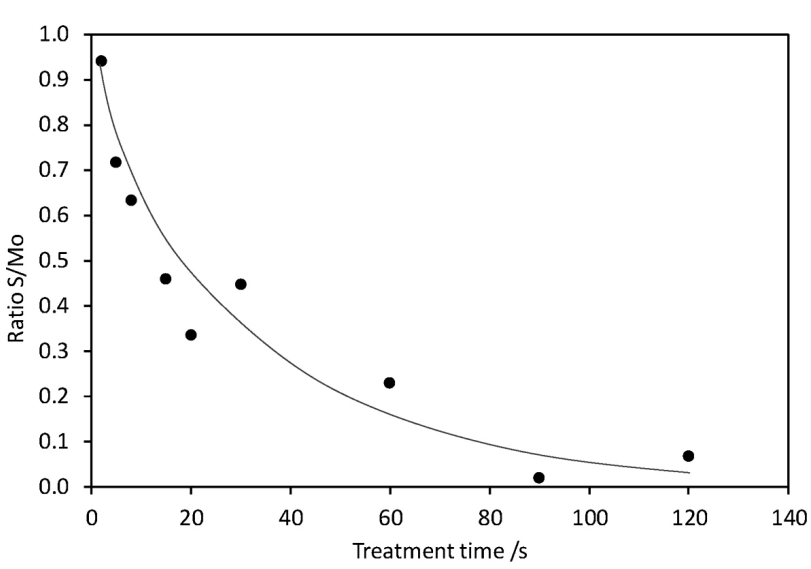

Figure 1: Variation of S/Mo ratio with treatment time

ment time, the concentration of oxygen exceeded the value for the untreated sample.

Figure 2 shows selected XPS spectra of Mo $3 \mathrm{~d}$ and S $2 \mathrm{~s}$ for the sulfurized molybdenum films. The molybdenum $3 \mathrm{~d}$ spectrum appears as a doublet consisting of Mo $3 \mathrm{~d}_{5 / 2}$ and Mo $3 \mathrm{~d}_{3 / 2}$ peaks. For the untreated sample Mo $3 \mathrm{~d}_{5 / 2}$ and Mo $3 \mathrm{~d}_{3 / 2}$ were positioned at $232.6 \mathrm{eV}$ and 235.8 $\mathrm{eV}$, respectively, and corresponded to $\mathrm{MoO}_{3}$ oxide, which is in agreement with the $\mathrm{O} / \mathrm{Mo}$ ratio in Table $\mathbf{1}$ and Figure 3a). After sulfurization for treatment times up to $15 \mathrm{~s}$ (samples with the highest sulphur concentrations), the main peak Mo $3 d_{5 / 2}$ was shifted to $229.3 \mathrm{eV}$, which was a consequence of the $\mathrm{MoS}_{2}$ formation. This will be discussed later in more details. Mo $3 \mathrm{~d}_{3 / 2}$ at $235.8 \mathrm{eV}$ almost disappeared, meaning that $\mathrm{MoO}_{3}$ has vanished. Furthermore, the $\mathrm{S} 2 \mathrm{~s}$ peak appeared as well. For treatment times between $20 \mathrm{~s}$ and $60 \mathrm{~s}$, a small peak of Mo $3 \mathrm{~d}_{3 / 2}$ at $235.8 \mathrm{eV}$ belonging to $\mathrm{MoO}_{3}$ appeared again, because for these samples the concentration of oxygen prevailed over the sulphur concentration according to Table 1. At the longest treatment times (90-120 s), where the concentration of sulphur was negligible and the concentration of oxygen was again very high, the

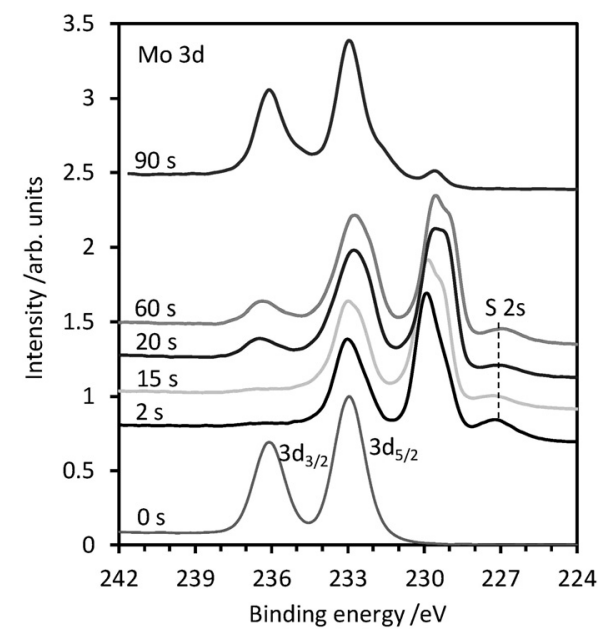

Figure 2: High-resolution XPS spectra of molybdenum for different treatments
Mo 3d peak became similar to the one measured for the untreated sample.

A more detailed deconvolution of the Mo $3 \mathrm{~d}$ peaks is shown in Figure 3. The spectra were fitted with the minimum number of peaks necessary to get the best matching. Here we should stress that during the reduction of $\mathrm{MoO}_{3}\left(\mathrm{Mo}^{6+}\right)$ oxide in plasma, oxides with the lower oxidation state (like $\mathrm{MoO}_{2}$ ) can be formed as well. Unfortunately, the $\mathrm{MoO}_{2}\left(\mathrm{Mo}^{4+}\right)$ peak overlaps with the $\mathrm{MoS}_{2}\left(\mathrm{Mo}^{4+}\right)$. Furthermore, also $3 \mathrm{~d}_{5 / 2}$ of $\mathrm{Mo}^{6+}$ in $\mathrm{MoO}_{3}$ overlaps with $3 \mathrm{~d}_{3 / 2}$ of $\mathrm{Mo}^{4+}$, which makes the chemical quantification of the XPS spectra difficult. Because of a lack of oxygen on the sample treated for $2 \mathrm{~s}$, the $\mathrm{Mo}^{4+}$ peak in Figure 3b was mostly attributed to the formation of $\mathrm{MoS}_{2 .}{ }^{15}$ The corresponding sulphur S $2 \mathrm{p}$ peak for this sample is shown in Figure 4. The $S 2 p_{3 / 2}$ peak at $162.2 \mathrm{eV}$ corresponds to $\mathrm{S}^{2-}$, thus confirming the formation of $\mathrm{MoS}_{2}$. No elemental sulphur at $164 \mathrm{eV}$ was found.

For the sample treated for $20 \mathrm{~s}$ which contained more oxygen, the $\mathrm{Mo}^{4+}$ peak can be attributed to both $\mathrm{MoS}_{2}$ and $\mathrm{MoO}_{2}$ (Figure 3c). Furthermore, an additional peak at $231.5 \mathrm{eV}$ was necessary to include to obtain a good fit. This peak was assigned to the $\mathrm{Mo}^{5+}$ state, which was also reported by Spevack. ${ }^{17}$ Moreover, also the Mo spectrum of the sample treated for $90 \mathrm{~s}$, which was similar to the untreated one, contained some presence of $\mathrm{Mo}^{5+}$ and $\mathrm{Mo}^{4+}$ species (Figure 3d). A peak belonging to pure $\mathrm{Mo}^{0}$ at $227.9 \mathrm{eV}$ was not observed on any of the samples.

According to the literature, high temperatures and long treatment times are desirable for the formation of high-quality stoichiometric $\mathrm{MoS}_{2}$ films. Therefore, it was surprising that the sulphur concentration was decreasing with treatment time (in our case, the longer treatment
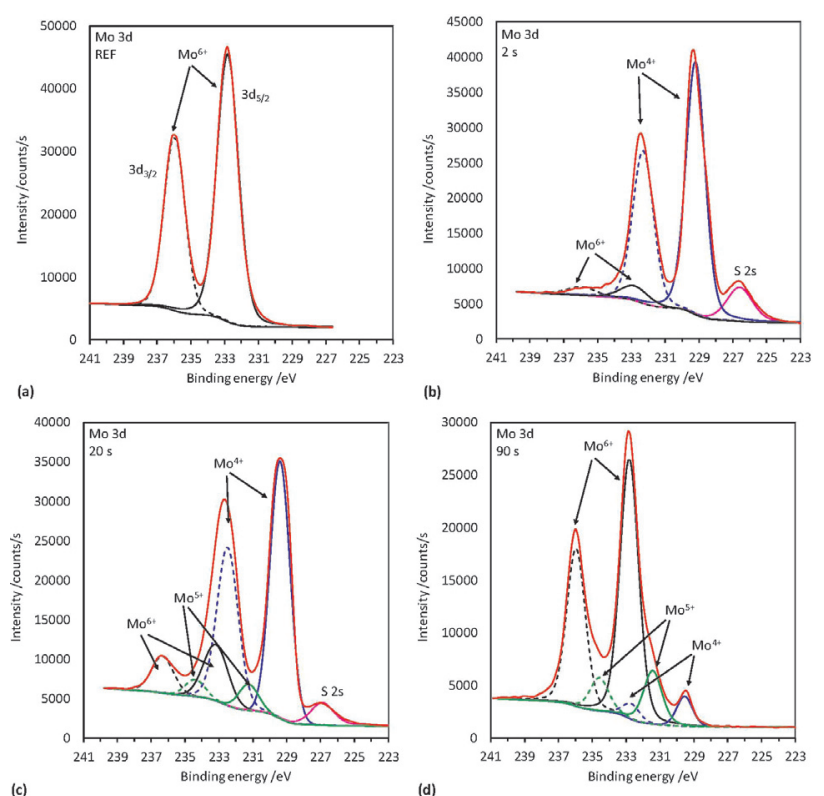

Figure 3: Detailed high-resolution XPS spectra of: a) the untreated sample and plasma-treated samples b) $2 \mathrm{~s}$, c) $20 \mathrm{~s}$ and d) $90 \mathrm{~s}$ 


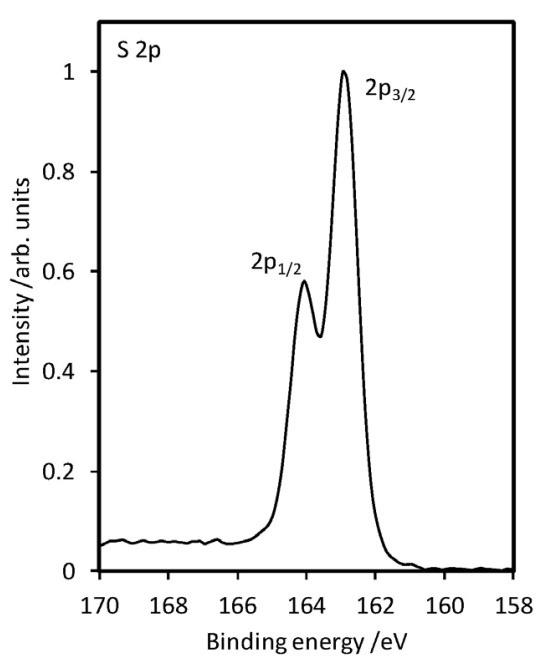

Figure 4: High-resolution XPS spectrum of sulphur for the sample treated for $2 \mathrm{~s}$

times also caused the higher surface temperature). Therefore, one sample was treated in pulses to prevent overheating (shown in Table 1). It can be observed that the $\mathrm{S} / \mathrm{Mo}$ ratio for this sample was higher than for the corresponding sample that was treated for the same time at once. It seems that at higher temperatures, $\mathrm{MoS}_{2}$ became unstable. To further explore this observation, we treated one sample in mild plasma conditions to avoid heating by plasma. Instead, a heater was used to maintain the sample temperature constant at $400{ }^{\circ} \mathrm{C}$ (this was the maximum temperature obtained by the heater). The treatment time was set to $30 \mathrm{~min}$ to have more similar time conditions as in the published literature presented in the Introduction. Although the amount of sulphur (in a/\%) appeared to be quite small, the ratio S/Mo was quite high. The apparently low sulphur concentration was a consequence of a relatively high carbon content (and also oxygen). As it will be shown later, the high carbon content was a consequence of the surface contamination. Nevertheless, we can conclude that a too high temperature might be detrimental and this explains a decrease in the sulphur with treatment time.

To estimate the sulphur film thickness, we performed XPS depth profiling of some selected samples, which are shown in Figure 5: a) for the as-received sample, b) for the sample with the maximum sulphur content (treated $2 \mathrm{~s}$ ), and c) for the sample treated $30 \mathrm{~min}$ at $400{ }^{\circ} \mathrm{C}$. For the untreated sample (Figure 5a), two oxidized layers can be observed. The upper one belonging to the $\mathrm{MoO}_{3}$ oxide, with a thickness of about $5 \mathrm{~nm}$ (taking into account the etching rate of approximately $1 \mathrm{~nm} / \mathrm{min}$ ) and the lower one, where some oxygen still persisted and extended far into the depth. For the sample treated for $2 \mathrm{~s}$ (Figure 5b), a reduction of the oxygen concentration was observed. Furthermore, the sulphur appeared only in a very thin layer at the surface with a thickness of approximately $5 \mathrm{~nm}$. The sulphur layer on the sample treated for $30 \mathrm{~min}$ was only slightly thicker. Furthermore, the high oxygen concentration found on the surface
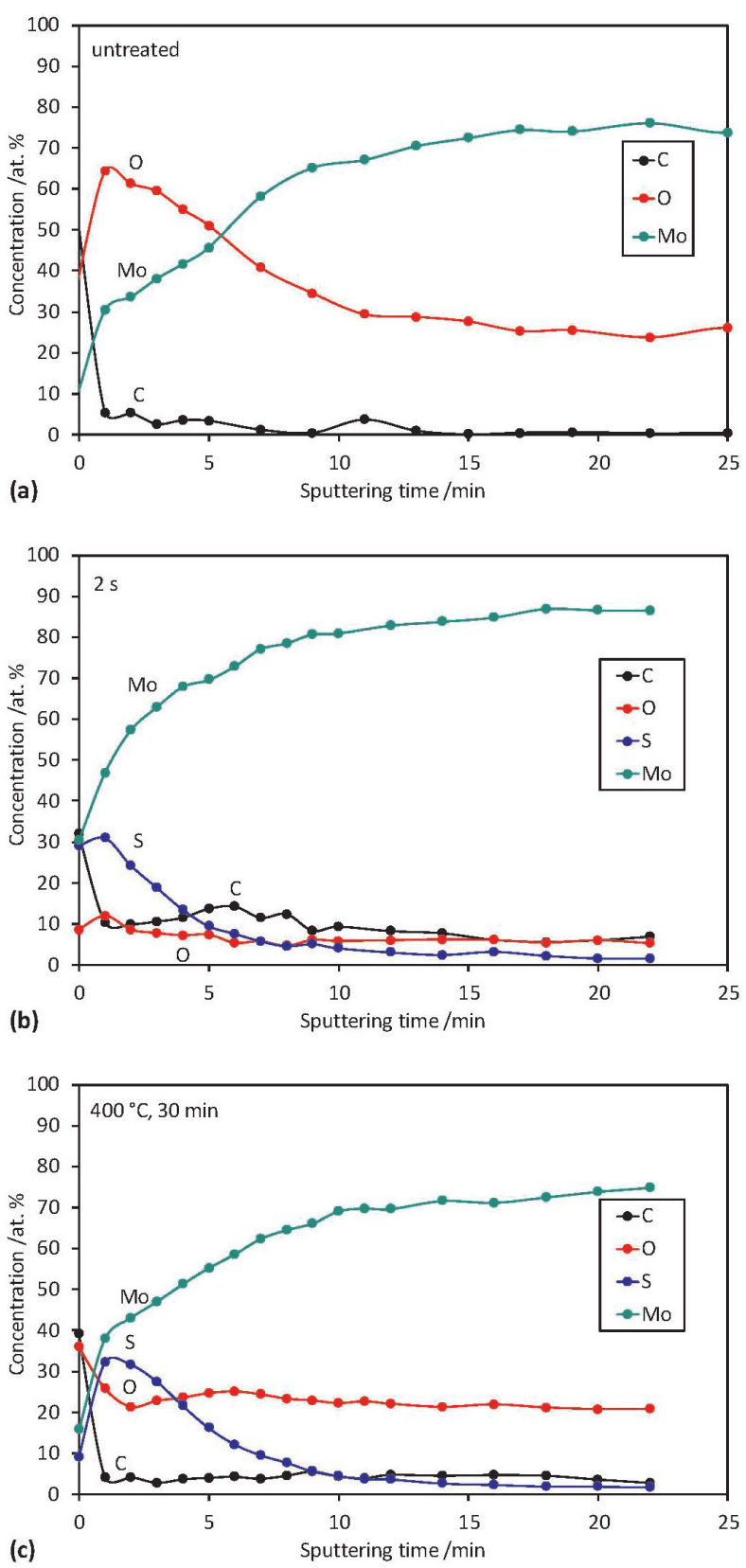

Figure 5: XPS depth profile of: a) the untreated molybdenum sample, b) the sample treated for $2 \mathrm{~s}$ and c) the sample treated for $30 \mathrm{~min}$ at $400{ }^{\circ} \mathrm{C}$

(Table 1) extended well into the bulk, meaning that it was not just the surface oxidation. In contrast, the carbon was found only at the surface, which was explained as a surface contamination from the heating device.

\section{CONCLUSIONS}

As-received $\mathrm{MoO}_{3}$ samples were treated for various periods in $\mathrm{H}_{2} \mathrm{~S}$ plasma created by a RF generator at 800 W. At $800 \mathrm{~W}$ the plasma was running in H-mode, which allowed for extensive sample heating. Already at the shortest treatment time ( $2 \mathrm{~s})$ the sample was red hot. This sample had the maximum sulphur concentration $(33 \%$ 
of amount fractions), whereas the oxygen content was very small only $6.6 \%$ of amount fractions (initially $\sim 35 \%$ of amount fractions). This result showed that oxygen was replaced by sulphur, leading to the formation of $\mathrm{MoS}_{2}$, as proved by the high-resolution XPS spectra as well. With the increasing treatment time, the sulphur concentration gradually decreased and became negligible at $90 \mathrm{~s}$ of treatment. Although high temperatures are desirable for a high-quality formation of $\mathrm{MoS}_{2}$, it is possible that under our treatment conditions the $\mathrm{MoS}_{2}$ was unstable and thus it decomposed.

\section{Acknowledgment}

The authors acknowledge the financial support from Slovenian Research Agency (bilateral project ARRSBI-USA/2016-17-001).

\section{REFERENCES}

${ }^{1}$ S. Najmaei, Z. Liu, W. Zhou, X. L. Zou, G. Shi, S. D. Lei, B. I. Yakobson, J. C. Idrobo, P. M. Ajayan, J. Lou, Vapour phase growth and grain boundary structure of molybdenum disulphide atomic layers, Nat. Mater., 12 (2013), 754-759, doi:10.1038/nmat3673

${ }^{2}$ A. Tarasov, P. M. Campbell, M. Y. Tsai, Z. R. Hesabi, J. Feirer, S. Graham, W. J. Ready, E. M. Vogel, Highly uniform trilayer molybdenum disulfide for wafer-scale device fabrication, Adv. Funct. Mater., 24 (2014), 6389-6400, doi:10.1021/acsami.5b11325

${ }^{3}$ L. Z. Hao, Y. J. Liu, W. Gao, Z. D. Han, Q. Z. Xue, H. Z. Zeng, Z. P. Wu, J. Zhu, W. L. Zhang, Electrical and photovoltaic characteristics of $\mathrm{MoS}_{2} / \mathrm{Si}$ p-n junctions, J. Appl. Phys., 117 (2015), 114502, doi:10.1063/1.4915951

${ }^{4}$ X. Li, H. Zhu, Two-dimensional $\mathrm{MoS}_{2}$ : Properties, preparation, and applications, J. Materiomics, 1 (2015), 33-44, doi:10.1016/j.jmat. 2015.03.003

${ }^{5}$ Y. B. Wu, W. Yang, T. B. Wang, X. H. Deng, J. T. Liu, Broadband perfect light trapping in the thinnest monolayer graphene- $\mathrm{MoS}_{2}$ photovoltaic cell: the new application of spectrum-splitting structure, Sci. Rep., 6 (2016), 20955, doi:10.1038/srep20955
${ }^{6}$ S. M. Bahauddin, H. Robatjazi, I. Thomann, Broadband absorption engineering to enhance light absorption in monolayer $\mathrm{MoS}_{2}$, ACS Photonics, 3 (2016), 853-862, doi:10.1021/acsphotonics.6b00081

${ }^{7}$ M. L. Tsai, S. H. Su, J. K. Chang, D. S. Tsai, C. H. Chen, C. I. Wu, L. J. Li, L. J. Chen, J. H. He, Monolayer $\mathrm{MoS}_{2}$ heterojunction solar cells, ACS Nano, 8 (2014), 8317-8322, doi:10.1021/nn502776h

${ }^{8}$ H. Wang, L. Yu, Y. H. Lee, Y. Shi, A. Hsu, M. L. Chin, L. J. Li, M. Dubey, J. Kong, T. Palacios, Integrated circuits based on bilayer $\mathrm{MoS}_{2}$ transistors, Nano Lett., 12 (2012), 4674-4680, doi:10.1021/ nl302015v

${ }^{9}$ B. Radisavljevic, A. Radenovic, J. Brivio, V. Giacometti, A. Kis, Single-layer $\mathrm{MoS}_{2}$ transistors, Nat. Nanotechnol., 6 (2011), 147-150, doi:10.1038/nnano.2010.279

${ }^{10} \mathrm{~S}$. Bertolazzi, J. Brivio, A. Kis, Stretching and breaking of ultrathin $\mathrm{MoS}_{2}$, ACS Nano, 5 (2011), 9703-9709, doi:10.1021/nn203879f

${ }^{11}$ Y. Hu, D. H. C. Chua, Synthesizing 2D $\mathrm{MoS}_{2}$ nanofins on carbon nanospheres as catalyst support for proton exchange membrane fuel cells, Sci. Rep., 6 (2016), 28088, doi:10.1038/srep28088

${ }^{12}$ C. Feng, J. Ma, H. Li, R. Zeng, Z. Guo, H. Liu, Synthesis of molybdenum disulfide $\left(\mathrm{MoS}_{2}\right)$ for lithium ion battery applications, Mater. Res. Bull., 44 (2009), 1811-1815, doi:10.1016/j.materresbull. 2009.05.018

${ }^{13}$ T. Weber, J. C. Muijsers, H. J. M. C. van Wolput, C. P. J. Verhagen, J. W. Niemantsverdriet, Basic reaction steps in the sulfidation of crystalline $\mathrm{MoO}_{3}$ to $\mathrm{MoS}_{2}$ as studied by X-ray photoelectron and infrared emission spectroscopy, J. Phys. Chem., 100 (1996), 14144-14150, doi:10.1021/jp961204y

${ }^{14}$ X. L. Li, Y. D. Li, Formation $\mathrm{MoS}_{2}$ inorganic fullerenes (IFs) by the reaction of $\mathrm{MoO}_{3}$ nanobelts and $\mathrm{S}$, Chem. Eur. J., 9 (2003), 2726-2731, doi:10.1002/chem.200204635

${ }^{15}$ P. Kumar, M. Singh, R. K. Sharma, G. B. Reddy, Reaction mechanism of core-shell $\mathrm{MoO}_{2} / \mathrm{MoS}_{2}$ nanoflakes via plasma-assisted sulfurization of $\mathrm{MoO}_{3}$, Mater. Res. Express, 3 (2016), 055021, doi:10.1088/2053-1591/3/5/055021

${ }^{16}$ P. Kumar, M. Singh, R. K. Sharma, G. B. Reddy, An experimental study: Role of different ambient on sulfurization of $\mathrm{MoO}_{3}$ into $\mathrm{MoS}_{2}$, J. Alloy. Compd., 671 (2016), 440-445, doi:10.1016/j.jallcom. 2016.02.097

${ }^{17}$ P. A. Spevack, N. S. Mcintyre, A Raman and XPS investigation of supported molybdenum oxide thin-films. 2. Reactions with hydrogen-sulfide, J. Phys. Chem., 97 (1993), 11031-11036, doi:10.1021/j100144a021 